\title{
Impact of Exclosure on Restoration of Degraded Lands and Carbon Stock Enhancement in Ethiopia, a Review
}

\author{
Diriba Megersa ${ }^{1, ~ *}$, Leta Hailu ${ }^{2}$ \\ ${ }^{1}$ Ambo Agricultural Research Center, Ambo, Ethiopia \\ ${ }^{2}$ Jimma Agricultural Research Center, Jimma, Ethiopia
}

Email address:

dmegersa81@gmail.com (D. Megersa)

${ }^{*}$ Corresponding author

\section{To cite this article:}

Diriba Megersa, Leta Hailu. Impact of Exclosure on Restoration of Degraded Lands and Carbon Stock Enhancement in Ethiopia, a Review. American Journal of Environmental Protection. Vol. 10, No. 4, 2021, pp. 77-83. doi: 10.11648/j.ajep.20211004.11

Received: May 7, 2021; Accepted: July 6, 2021; Published: July 15, 2021

\begin{abstract}
Land degradation due to forest loss is the most challenging problem in sub-Saharan countries including Ethiopia. The forest coverage of the country has been declined at an alarming rate. Currently, exclosure practice is part of the community mass mobilization of soil and water conservation program in the country as a means to reverse land degradation problem. The involvement of either of the exclosure intervention methods (passive or active) could enhance plant regeneration (seedlings, saplings, shrubs, under stories, and woody vegetation) including the diversity of all woody species, grass and herbs and biomass carbon stock of the terrestrial ecosystem. It then can control splash erosion by providing sufficient surface cover that reduces the amount and velocity of runoff. Additionally, the exclosure could play a significant role in generating income from non-timber forest product such as bee keeping, fattening by cut and carry feeding system to improve the livelihood of the community. These can be considered as the opportunities to promote the enclosure practice. However, the controversies are the burden of shrinkage and overstocking of livestock on the remaining grazing land, inequitable benefit-sharing for the local communities and unaccountability of exclosure management, monitoring, and lack of the management plan. These are upsetting challenges in the exclosure program of Ethiopia.
\end{abstract}

Keywords: Challenges, Exclosure, Ethiopia, Land Degradation, Opportunities

\section{Introduction}

Nowadays, from the existing world terrestrial ecosystem, about $25 \%$ of it has been degraded [1]. It is one of the most challenging problems primarily in sub-Saharan countries $[2$, 3]. Ethiopia is one of the sub-Saharan countries that have been sharing this problem. Land degradation has been challenging the country by reducing the productivity of the land [4].

The natural resource (Primarily the forest resource) depletion beyond their recovering capacity [2], has been aggravated by population growth, an agricultural expansion that causes vast area deforestation, poverty and overgrazing [5-7]. That is why the forest coverage of Ethiopia has been impaired from $16 \%$ during 1950 , to $2.2 \%$ during 2000 [8]. Furthermore, the forest cover of the country has been declined at an alarming rate from the year 1990 to 2000 by
140,900 ha or $0.93 \%$ per year. Accordingly, Ethiopia has lost about $18.6 \%$ of its forest cover or around 2,818,000 hectares of forest cover from 1990 to 2010, which is the root causes for the thriving of the land degradation in the country [6]. Additionally, the FRA, 2015 report revealed that the estimated forest loss of 768,491 ha, which is about $1.33 \%$ per year from 2010 to 2015 .

The loss of the fertile soil by water erosion and siltation of the downstream villages and dams are the result of this deforestation and land degradation; which is a serious problem that has been challenging the country [9]. Even though the re-greening Ethiopia was started since the 1890's without significant achievements of the planned goal in forest cover yet [10]. Currently, the Ethiopian government has been encouraging the mass mobilization for the construction of physical and biological measures of soil and water conservation in order to reduce this overgrowing land degradation. Consequently, exclosure is one of the 
involvements of this mobilization [3, 11], which is an ultimate solution for the ongoing land degradation by being the rehabilitation tool [12]. Likewise, it can reverse the degraded land and rehabilitate the area that being out of use, avoid or reducing human-induced erosion, flood and land degradation $[12,13]$. It can also assist the natural vegetation succession, besides; being substitutes for deforestation and land degradation, those have been taking place. Therefore, this paper was intended to review the impact of exclosure on restoration of degraded lands and carbon stock enhancement to summarize the intervention effort in the Country.

\section{The Overview of Exclosure}

Exclosures and enclosures are related terms; though, cannot be used synonymously. In some cases, peoples may use 'Enclosure' and 'Exclosure' synonymously; however, they are not synonyms. Literally, they seem synonymous. However, in ecological science, they have a little difference in meaning. For examples: -exclosure means, excluding animals and or peoples from entering (disturbing) a given area or site. While, the enclosure means, confining something (Animals) in a given area or site, in order to prevent their movement outside of the area. Therefore, using both terms as synonyms may lead to incorrect understanding [14].

In broad terms, exclosures are the areas of degraded land that protected from the interference (disturbance) of different domestic animals (livestock grazing) and human, in order to promote the natural regeneration of vegetation (succession process) or artificial plantation to assist the recovery rate or the combination of the practice [15]. The exclosure activity involves two management practices: Passive and active exclosure intervention methods. The passive exclosure intervention method is excluding both human and livestock from the area and leave the regeneration process for nature. The active exclosure intervention method is assisting the natural regeneration capacity of vegetation by plantation and different physical soil and water conservation activities in order to reduce the erosion risk $[10,12,15]$. The enclosure was started in England and Wales (one of the four countries that make up the United Kingdom of Great Britain and Northern Ireland) in the thirteenth century [14]. Currently, more than 3 million hectares (ha) of degraded forestland are under area exclosure worldwide [10].

In Ethiopia, exclosure is supposed as a young science about only three decades; however, the re-greening Ethiopia was started during 1890s more than one century ago. It was designed as an alternative approach to re-greening through reforestation and afforestation. During this time, "re-greening" was encompassed all forms of management practices and other measures and planned to rehabilitate degraded forest lands [16]. Today, area exclosure is one type of re-greening program in Ethiopia, which is expanding rapidly. During 1996, there was only about 143,000 ha of exclosure in Ethiopia; while, it reached 895,220 ha in 2011 [17, 18]. So that, effectiveness of the exclosure could be measured through evaluation of its impact on vegetation recovery, biomass and soil organic carbon stock enhancement [19].

\section{Exclosure as Tools for Rehabilitation of the Degraded Lands}

\subsection{Exclosure on Enhancing the Vegetation Recovery and Biomass Carbon Stock}

The exclosure management practices involves either passive or active intervention methods $[10,12]$. The passive exclosure intervention method is excluding both human and livestock from the area and permit the regeneration process for nature; whereas, the active exclosure intervention method is assisting the natural regeneration capacity of vegetation by plantation and different engineering conservation activities $[10,12,13]$.

The exclosure can enhance plant regeneration (restore degraded native vegetation) and conserve the biodiversity of a given ecosystem by using either of these intervention methods. Likewise, it is effective in restoring degraded native vegetation and can be used as a source of seeds of indigenous woody species through long periods. Consequently, excluding livestock and human disturbance from a given degraded area is significantly allow the recovery of degraded vegetation and conserve biodiversity [20-23]. Additionally, the role of an exclosure on reducing deforestation from their boundaries is the supplementary contribution to enhance the vegetation recovery of a given ecosystem [24].

Numerous scholars have been proven that the establishment of an exclosure on the degraded grazing land could significantly enhance the number of individual woody species in an exclosure than the open grazing land [25-28]. Moreover, it could bring a significant difference in species composition, structure, density, and diversity than the open grazing land as well $[20,22,28,29]$. In other ways, the vegetation recovery rate of the exclosure could be determined by the age of the exclosure [22, 28, 30]. For instance, different scholars have been reported the higher number of individual woody species and species diversity in the exclosure of age 13 years [25], age more than 10 years and 22 years of exclosure establishment [22, 24, 29].

Generally, the establishment of an exclosure on degraded grazing land could enhance the vegetation recovery (seedlings, saplings, shrubs, understory and woody vegetation) including the diversity of all woody species, grass and herbs than the open grazing land [28]. This suggesting the exclusion of the livestock grazing and human disturbance from the degraded grazing land (establishing the exclosure) use can improve the above and below ground biomass carbon stock by supporting the vegetation recovery [13, 30-32].

In Ethiopia, several studies have been reported the role of an exclosure on enhancing the biomass carbon stock of the terrestrial ecosystem [13, 33-37]. Similarly, the higher above ground biomass (AGB) and belowground biomass (BGB) carbon stock in exclosure land uses than the adjacent open grazing lands [13, 26]. Accordingly, [13], had reported the 
average difference of AGB carbon stock of 2.3 to $5.6 \mathrm{t} \mathrm{c} / \mathrm{ha}^{-1}$, in the highlands of Tigray. Additionally, Mekuria, 2013, also reported 2.0 to $7.0 \mathrm{t} \mathrm{c} \mathrm{ha}^{-1}$ in the exclosure of (age 20). The study conducted on the exclosure of age 20 years old, in China, by [38]. Indeed, the above ground biomass carbon could be influenced by the age of exclosure $[36,38]$.

\subsection{Role of Exclosure on Reducing Erosion and Land Degradation}

The increasing demand of rapidly increasing human population in the country had been resulting in the exploitation of natural resources specifically forest resources outside their recuperating capacity [39]. It has been exposing the country for serious land degradation due to soil erosion by water [40]. Additionally, cultivation on steep slopes and clearing of vegetation has accelerated this erosion and land degradation problem [41].

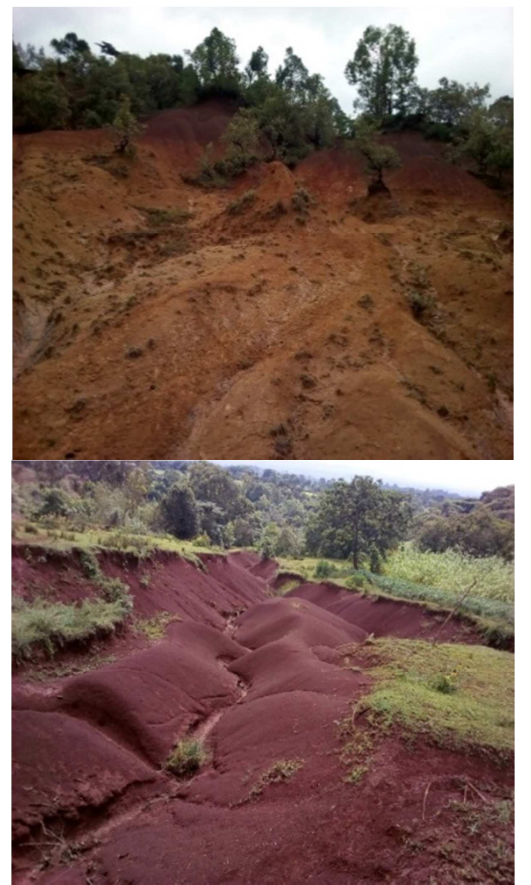

Figure 1. Land degradation due to severe soil erosion at Tiro Afeta district, Jimma zone of southwestern Ethiopia.

Source: Field photo taken during field observation for intervention of integrated watershed management, 2020.

Different scholars had reported that establishments of exclosure are a type of land management with spatial emphasis to recover the environmental conditions and controlling soil erosion in degraded open access lands $[3,13$, $34,42]$. The exclosure could restore the degraded native vegetation through natural succession or human assists of establishing plantation and physical structures [21-23]. It then can control splash erosion by providing sufficient surface cover, while transportation of soil by surface runoff can be reduced by regulating its velocity using physical structures (e.g. bund structures, trenches, micro-basins, and hillside terraces) and vegetative measures [43].
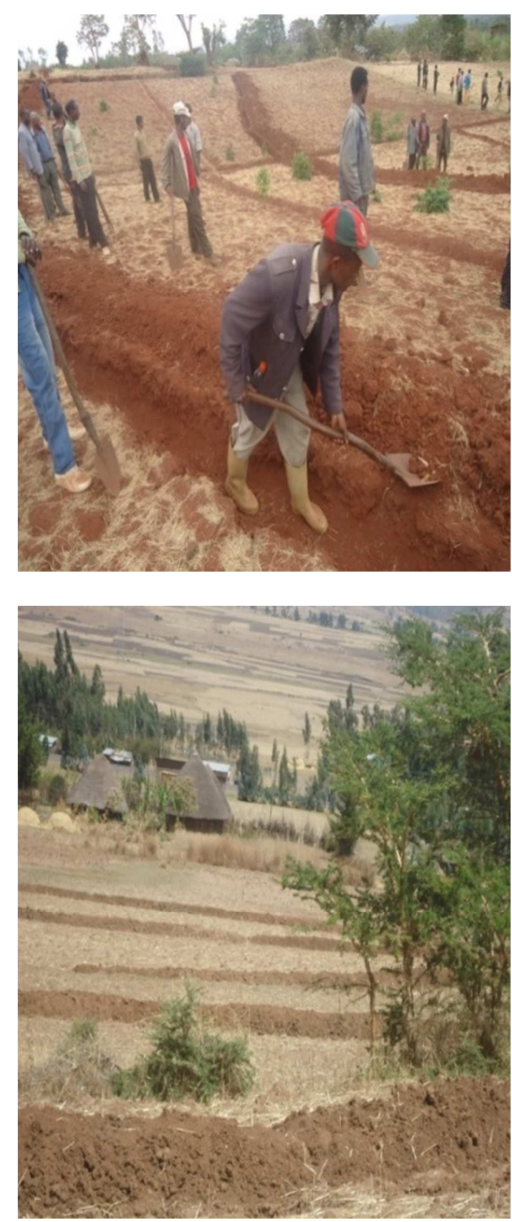

Source: Woliso district Agricultural office, 2012.

Figure 2. Physical soil and water conservation structures constructed by community participation, woliso district of southwest of Ethiopia.

Hence, the ultimate principle of reducing soil erosion by water is to reduce the amount of runoff and velocity as much as possible. Likewise, the physical measures assisted in the exclosure can reduce runoff velocity, enhance water infiltration and traps sediment at the downstream section of the structures [43, 44].

The study conducted by W. Mekuria et al shows that 10 years old exclosure had reduced estimated soil erosion by $77 \%$ (from 52 to $12 \mathrm{Mg} \mathrm{ha}^{-1} \mathrm{y}^{-1}$ ) [13]. M. Mekuria and E. Aynekulu have also reported the higher total soil nitrogen $(\mathrm{N})$, available phosphorus $(\mathrm{P})$, and cation exchange capacity in 20-years old exclosure than the communal grazing lands; which is indicative of nutrient improvement [35]. This could be because exclosures have been restored the land cover, shrubs and understory vegetation which are a barrier for detachment and transportation of soil [13, 23]. Other studies had forwarded similar ideas on vegetation recovery and reduced soil loss. The case studies conducted on exclosures in different parts of the country suggested that exclosures had exhibited twice the plant species richness and diversity value compared with communal grazing lands [45]. For example, after 22 years of exclosure establishment, an increase in woody species richness of 13 after 8 years of exclosure establishment was reported in [46]. 
Similarly, an increase in soil organic carbon of $1.1 \%$, total $\mathrm{N}$ of $0.1 \%$, and available $\mathrm{P}$ of $1.8 \mathrm{mg} \mathrm{ha}^{-1}$ after 10 years of exclosure establishment was reported by [26]. Additionally, a substantial decrease in soil loss was reported after the establishment of exclosures on communal grazing lands [13, $34,47]$. These all have confirmed the important role of exclosure on the erosion control and degraded land rehabilitation.
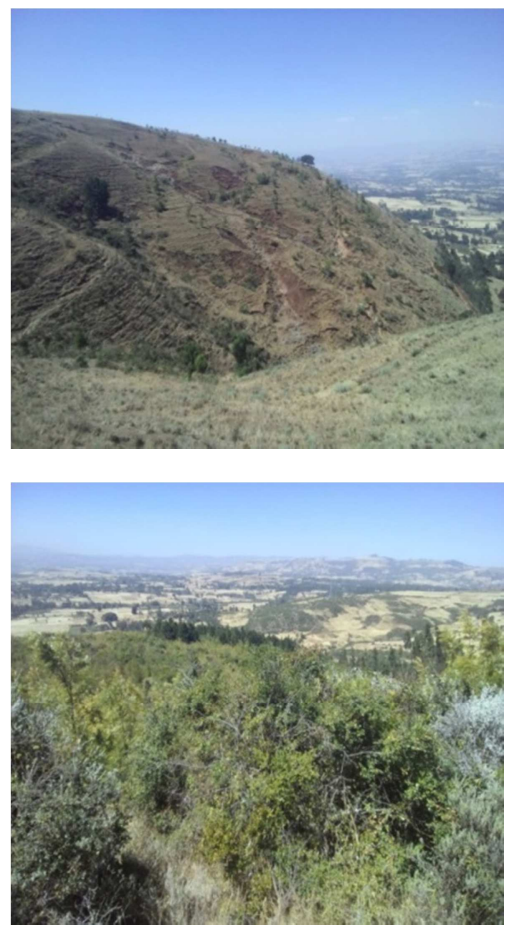

Source: Photos taken from Exclosure around Woliso, Southwestern Ethiopia.

Figure 3. Effect of exclosure on vegetation recovery in Woliso district, southwestern Ethiopia.

\section{Opportunities, Challenges and Management of Exclosures in Ethiopia}

\subsection{Opportunities in Management of Exclosure}

The current mass mobilization for the construction of physical and biological measures of soil and water conservation in the country is one of the opportunities that has been set the foundation for the establishment of an exclosure as tools for rehabilitation of the degraded areas [3, $11,12]$.

\subsection{Challenges of Exclosure Management}

The issue of the earning short term benefit from the exclosure area is the most challenging problem; since, the local community seriously demanding short term benefit from it [11, 48]. Additionally, shrinkage of the remaining grazing land and overstocking of the livestock to the remaining grazing lands are sensitive concerns in the establishment of an exclosure and its management [10, 49].

Another challenging issue is the issue of ownership. In many rural communities, taking responsibility during managing and protection of the exclosure is the arguable tricky. For example, the allocation of the communally managed exclosure area to individuals in different regions or zones of the country could devastate the trust of the community on the ownership of the exclosure and affect their willingness to participated in the exclosure program. Furthermore, the lack of management plans and aiding agencies centered initiation of the exclosure program are some of the challenges that faced the management of the exclosure [10].

In terms of the utilization of the resources in the exclosure, one may exploit the resource, while others are stand sideway; since this could offend the equity of the communities' resource sharing $[10,11,50]$. Likewise, grazing of animals, cutting trees for a different purpose by unconvinced peoples and conflicts between adjacent communities are other obstacles for the sustainable management of the exclosure $[51,52]$.

Many of the rural communities are obviously depend on forest resources; thus, ensuring the income contribution of the exclosure area for those dependent communities is to be an important activity in order to reduce the further degradation [11]. In order to sustain the lifespan of an exclosure program and prevent further degradation of the ecosystems, the local communities need to be benefited sustainably from the exclosure [11, 48]. Consequently, the promotion of alternative livelihood and increasing the income contribution of the exclosure area for those dependent communities are the critical strategic options for reducing deforestation and restoration of degraded areas [11, 50]. If sufficient economic incentives were not generated for the communities and the goals of the exclosure establishment is only for environmental protection, the sustainability of any exclosure program is obviously being in question [10, 11, 48].

In other ways, it has been recognized by authors that, an exclosure can provide an income, such as livestock fattening, grass seed harvesting, honey production, dry season feed, hatching grass and hay baling for local communities; which has been considered as opportunity for sustainable management of the exclosure [20, 21]. Additionally, it can provide an ecosystem service (restoring the degraded soil by improving the soil fertility, regeneration of lost species of trees and grasses, reduction of flood and erosion hazard from the downstream areas) $[35,49,53]$. However, in most parts of the country, organizing these benefits and sharing the benefits in an equitable way is still being a headache [10].

\section{Conclusion}

Generally, researchers have reported Exclosure as a tool for the restoration activity. The establishment of the exclosure with plantation intervention enhances the vegetation recovery of the degraded ecosystem. It could significantly enhance the number of individual woody species, species composition, structure, density, and diversity. Besides, it can be used as a source of seeds of indigenous 
woody species through a long period since the exclosure age has a significant effect. Therefore, the establishment of an exclosure on open degraded landscapes can improve the above and below ground biomass carbon stock by supporting the vegetation recovery; which is the backbone for biomass production.

The exclosure has another significant role in reducing the serious soil erosion and land degradation that has been taking place due to cultivation on steep slopes and clearing of vegetation in day-to-day human activities. It has the potential of reducing soil erosion by providing sufficient surface cover. This surface cover can reduce erosion by preventing the splash erosion (detachment process) and reducing the runoff velocity, and enhancing the infiltration rate. Consequently, the exclosure could enhance the soil nutrients by improving the ecosystem services (restoring the degraded soil by improving the soil fertility, regeneration of lost species of trees and grasses, reduction of flood and erosion hazard from the downstream areas). Additionally, exclosure could improve the livelihood of the community by providing incomes: livestock fattening, grass seed harvesting, honey production, dry season feed, hatching grass and hay baling. These are more or less; the opportunities in managing the exclosure sustainably and part of the mechanism of sustaining the exclosure program and prevent further degradation.

Despite its merit, exclosure imposes the burden of shrinkage and overstocking of livestock on the remaining grazing land. Therefore, its sustainability can be threatened. Likewise, inequitable benefit-sharing for the local communities and unaccountability of exclosure management, monitoring, and lack of the management plan are some of alarming challenges in the exclosure program of Ethiopia. Therefore, to sustain the exclosure management and reduce its negative impact of shrinking the grazing land area, strategies need to be developed as a solution. Platform of Equitable sharing of benefit and sense of accountability should be created in the country and as well as in the mind of the community for ensuring social affairs. Additionally, the exclosure management plan and monitoring documents should be developed, practiced and realistic to secure exclosure program of Ethiopia.

\section{References}

[1] FAO. 2011. The state of the world's land and water resources for food and agriculture (SOLAW) - managing systems at risk Food and Agriculture Organization of the United Nations, Rome and Earthscan, London.

[2] H. Hurni, K. Tato, and G. Zeleke (2005) The implications of changes in population, land use, and land management for surface runoff in the upper Nile basin area of Ethiopia. Mountain Research and Development 25 (2): 147-154.

[3] B. Nedessa, J. Ali, I. Nyborg (2005) Exploring ecological and socio-economic issues for the improvement of area enclosure management. A case study from Ethiopia. DCG report No. 38, $3-30$.
[4] M. M Ayenew and B. Kopainsky (2014) Food insecurity in Ethiopia: population, food production and market. In Proceedings of the $32 \mathrm{nd}$ international conference of the system dynamics society, Delft. The Netherlands.

[5] I. P. O. C Change, (2007) Climate change 2007. The physical science basis. Agenda, 6 (07): 333.

[6] FAO (Food and Agriculture Organization of the United Nations). 2010. Global forest resources assessment in: Bahamondez, C., Christophersen, T., Csoka, P., Drichi, P., Filipchuk, A., Gueye, S., Johnson, S., Kajarlainen, T., Kapos, V. and Keenan, R. Global forest resources assessment 2010 main report.

[7] R. J Keenan, G. A Reams, F. Achard, J. V. de Freitas, A. Grainger, and E. Lindquist, (2015) Dynamics of global forest area: results from the FAO global forest resources assessment. Forest ecology and management, (352): 9-20.

[8] L. Berry (2003) Land degradation in Ethiopia: Its extent and impact. Commissioned by the GM with WB support, pp 2-7.

[9] W. Bewket and E. Teferi (2009) Assessment of soil erosion hazard and prioritization for treatment at the watershed level: case study in the Chemoga watershed, Blue Nile basin, Ethiopia. Land degradation \& development 20 (6): 609-622.

[10] M. Lemenih, and H. Kassa (2014) Re-greening Ethiopia: history, challenges and lessons. Forests, 5 (8): 1896-1909.

[11] S. Grey and K. Joosten (2016) Climate smart initiative: area closure, FAO sub-regional office for Eastern Africa, Addis Ababa, Ethiopia.

[12] Ministry of Agriculture (MoA). 2016. Sustainable agriculture through watershed management. In natural resource management directorate. The training manual, enclosed and rehabilitated area management-guideline draft, Addis Ababa, Ethiopia.

[13] W. Mekuria, E. Veldkamp, M. Haile, K. Gebrehiwot, B. Muys, and J Nyssen (2009) Effectiveness of exclosures to control soil erosion and local community's perception on soil erosion. African journal of agricultural research, 4 (4): 365-377.

[14] R. Aerts, J. Nyssen and M. Haile (2009) The difference between" exclosures" and" enclosures" in ecology and the environment. Journal of arid environments, 73 (8): 762763.

[15] W. Mekuria, J. Barron, M. Dessalegn, Z. Adimassu, T. Amare, and M. Wondie (2017) Exclosures for ecosystem restoration and economic benefits in Ethiopia: a catalogue of management options, international water management institute (IWMI). CGIAR research program on water, land and ecosystems (WLE).

[16] M. Bekele (2003) Forest property rights, the role of the state, and institutional exigency, (Vol. 409).

[17] M. Gebresilassie (2013) Forest development endeavors in Tigray region: opportunities, challenges and way forward. In proceedings of the workshop organized by CIFOR Ethiopia office, Addis Ababa, Ethiopia, (Vol. 29).

[18] M. Yami, W. Mekuria and M. Hauser (2013) The effectiveness of village bylaws in sustainable management of communitymanaged exclosures in northern Ethiopia. Sustainability science, 8 (1): 73-86. 
[19] T. Woldemariam (2015) GHG emission assessment guideline volume II: aboveground biomass field guide for baseline survey federal democratic republic of Ethiopia, Ministry of Agriculture, Addis Ababa, Ethiopia. Echnoserve consulting.

[20] T. Mengistu, D. Teketay, H. Hulten, and Y. Yemshaw (2005a) The role of enclosures in the recovery of woody vegetation in degraded dryland hillsides of central and northern Ethiopia. Journal of Arid Environments 60 (2): 259-281.

[21] S. Mureithi (2012) Effect of enclosures on the restoration of degraded semi-arid rangeland in Lake Baringo Basin, Kenya, Ph. D. thesis.

[22] W. Mekuria and M. Yami (2013) Changes in woody species composition following establishing exclosures on grazing lands in the lowlands of northern Ethiopia. African journal of environmental science and technology, 7 (1): 30-40.

[23] T. Gidey and V. Veen (2014) The effect of enclosures in rehabilitating degraded vegetation: a case of Enderta district, northern Ethiopia. Forest research, 3 (4): 12.

[24] S. Clark, K. Bolt and A. Campbell (2008) Protected areas: an effective tool to reduce emissions from deforestation and forest degradation in developing countries. UNEP-WCMC, Cambridge, UK.

[25] E. Birhane, D. Teketay and P. Barklund (2006) Actual and potential contribution of exclosures to enhance biodiversity of woody species in the drylands of eastern Tigray. Journal of the drylands, 1 (2): 134-147.

[26] W. Mekuria, E. Veldkamp, H. Mitiku, J. Nyssem, B. Muys, G. Kindeya (2007) Effectiveness of exclosures to restore degraded soils as a result of overgrazing in Tigray, Ethiopia. Journal of arid environments, 69: 270-284.

[27] D. Teketay, M. Lemenih, T. Bekele, Y. Yemshaw, S. Feleke, W. Tadesse, Y. Moges, T. Hunde, and D. Nigussie (2010) Forest resources and challenges of sustainable forest management and conservation in Ethiopia. Degraded forests in eastern Africa: management and restoration: 19-63.

[28] E. Birhane, D. Teketay, P. Barklund (2007) Enclosures to enhance woody species diversity in the dry lands of eastern Tigray, Ethiopia. East african journal of sciences, 1: 136-147.

[29] T. Yayneshet (2011) Restoration of degraded semi-arid communal grazing land vegetation using the exclosure model. International journal of water resources and arid environments, 1 (5): 382-386.

[30] M. Yami, K. Gebrehiwot, S. Moe, W. Mekuria (2006) Impact of area enclosures on density, diversity, and population structure of woody species: the case of May Ba'ati-DougaTembien, Tigray, Ethiopia. Ethiop J Nat Resource 8 (1): 99-121.

[31] M. H. Abebe, G. Oba, A. Angassa and R. B Weladji (2006) The role of area enclosures and fallow age in the restoration of plant diversity in northern Ethiopia. African journal of ecology, 44 (4): 507-514.

[32] W. Mekuria, E. Veldkamp (2012) Restoration of native vegetation following exclosure establishment on communal grazing lands in Tigray, Ethiopia. Appl Veg Sci. 15: 71-83.

[33] C. B Pandey, K. S. Pandya, D. Pandey and R. B. Sharma (2000) Growth and productivity of rice (Oryza sativa) as affected by Acacia nilotica in a traditional agroforestry system. Tropical ecology, 40 (1): 109-117.
[34] K. Descheemaeker, B. Muys, J. Nyssen, J. Poesen, D. Raes, M. Haile and J. Deckers, (2006) Litter production and organic matter accumulation in exclosures of the Tigray highlands, Ethiopia. Forest ecology and management, 233 (1): 21-35.

[35] M. Mekuria, E. Aynekulu (2011) "Exclosure land management for restoration of the soils in degraded communal grazing lands in northern highlands of Ethiopia" Land degradation and development, 2011.

[36] W. Mekuria 2013. Changes in regulating ecosystem services following establishing exclosures on communal grazing lands in Ethiopia: a synthesis. Journal of ecosystems, June 26.

[37] O. Salunkhe, P. K Khare, D. R. Gwalwanshi, S. Uniyal (2014) Biomass estimation from herb, shrub and litter component of tropical dry deciduous forest of Madhya Pradesh State of India. The journal of ecology, 109: 358-362.

[38] W. Mekuria, S. Langan, R. Johnston, B. Belay, D. Amare, T. Gashaw, G. Desta, A. Noble \& A. Wale (2015) 'Restoring aboveground carbon and biodiversity: a case study from the Nile basin, Ethiopia' Forest Science and Technology, DOI: 10.1080/21580103.2014.966862.

[39] H. Hurni, S. Abate, A. Bantider, B. Debele, E. Ludi, B. Portner, B. Yitaferu, and G. Zeleke (2010) Land degradation and sustainable land management in the highlands of Ethiopia.

[40] Z. Adimassu, A. Kessler, H. Hngsdijk (2012) Exploring determinants of farmers' investments in land management in the Central Rift Valley of Ethiopia. Applied geography, (35): 191-198.

[41] G. Birhane and K. Mekonen (2009) Estimating soil loss using universal soil loss equation (USLE) for soil conservation planning at Medego watershed, northern Ethiopia. Journal of american science, 5: 58-69.

[42] F. Yimer, G. Alemu and A. Abdelkadir (2015) Soil property variations in relation to exclosure and open grazing land use types in the central rift-valley area of Ethiopia. environmental systems research, 4 (1): 17.

[43] J. Nyssen, W. Clymans, J. Poesen, I. Vandecasteele, S. De Baets, N. Haregeweyn, J. Naudts, A. Hadera, J. Moeyersons, M. Haile (2009) How soil conservation affects the catchment sediment budget-a comprehensive study in the north Ethiopian highlands. Earth surface processes and landforms, 34: 1216-1233.

[44] H. Mitiku, K. Herweg, B. Stillhardt (2006) Sustainable land management: a new approach to soil and water conservation in Ethiopia. Centre for development and environment (CDE) and NCCR North-South, University of Bern, Switzerland. DOI: $10.7892 /$ boris. 19217 .

[45] M. Tefera, T. Demel, H. Håkan, Y. Yonas (2005) The role of enclosures in the recovery of woody vegetation in degraded dryland hillsides of central and northern Ethiopia. Journal of arid environments 60: 259-281.

[46] B. Emiru, D. Teketay, and P. Barklund (2006) "Actual and potential contribution of exclosures to enhance biodiversity of woody species in the drylands of Eastern Tigray." Journal of the Drylands 1. 2: 134-147.

[47] Girmay G, Singh BR, Nyssen J, Borrosen T. 2009. Runoff and sediment associated nutrient losses under different land uses in Tigray, Northern Ethiopia. Journal of hydrology 376: 70-80. 
[48] Yayneshet, T., Eik, L. O. and Moe, S. R. 2009. The effects of exclosures in restoring degraded semi-arid vegetation in communal grazing lands in northern Ethiopia. Journal of arid environments, 73 (4): 542-549.

[49] E. Birhane, T. Mengistu, Y. Seyoum, N. Hagazi, L. Putzel, M. M Rannestad and H. Kassa (2017) Exclosures as forest and landscape restoration tools: lessons from Tigray Region, Ethiopia. International forestry review, 19 (4): 37-50.

[50] A. Regassa, L. Likassa, S. Sebuh, T. Gonfa, T. Tadesse, Y. Moges (2014) Emissions reductions at the landscape level in the Oromia Region, Ethiopia, Ministry of Agriculture Oromia forest and wildlife enterprise Farm Africa / SOS Sahel Ethiopian forest coffee forum.
[51] A. Berhe (2014) The ecological impacts of exclosures in the highlands of Tigray, Northern Ethiopia. M. Sc. Thesis, Mekele University Department of LRMEP.

[52] G. Mulugeta, M. Achenef (2015) Socio-economic challenges of area exclosure practices: A case of Gonder Zuria Woreda, Amhara Region, Ethiopia Journal of natural sciences research 5: 13 .

[53] E. Birhane (2002) Actual and potential contributions of enclosures to enhance biodiversity in drylands of eastern Tigray, with particular emphasis on woody plants. M. Sc. Thesis. Swedish University of Agricultural Sciences (SLU), Sweden. 